\title{
Polygalacturonase Production by Aspergillus Niger Solid State Fermentation on Barley Bran and Sugar Beet Pulp Mixture
}

\author{
Aboalhasan Alavi*, Farahnoosh Tahghighi Nia, Farshid Pajoum Shariati \\ Department of Chemistry Engineering, Science and Research branch, Islamic Azad University, Tehran, Iran
}

\section{ART I CLE IN F O}

Received: 11 September 2019

Revised: 17 September 2019

Accepted: 05 October 2019

Available online: 07 October 2019

\section{K E Y W O R D S}

Polygalacturonase Solid state fermentation Aspergillus niger

Barley bran

Sugar beet pulp

\section{A B S T R A C T}

In this research, barley bran mixtures with sugar beet pulp were used for polygalacturonase enzyme production by Aspergillus niger fungus in solid state fermentation method for the first time. Effect of some factors including carbon sources relative composition, fermentation time, fermentation temperature, inoculation amount, and moisture content were investigated and optimized amounts were selected. Different mixtures of barley bran and sugar beet pulp with various relative compositions were studied and highest enzyme activity was found for $50 \% \mathrm{w} / \mathrm{w}$ of barley bran and sugar beet pulp. Incubation temperature of $30{ }^{\circ} \mathrm{C}$, time duration of 7 days, moisture content of $80 \% \mathrm{w} / \mathrm{w}$, and 10 million spores per gram of dry substrate were selected as optimum amounts.

GRA P H I C A L A B S T RACT

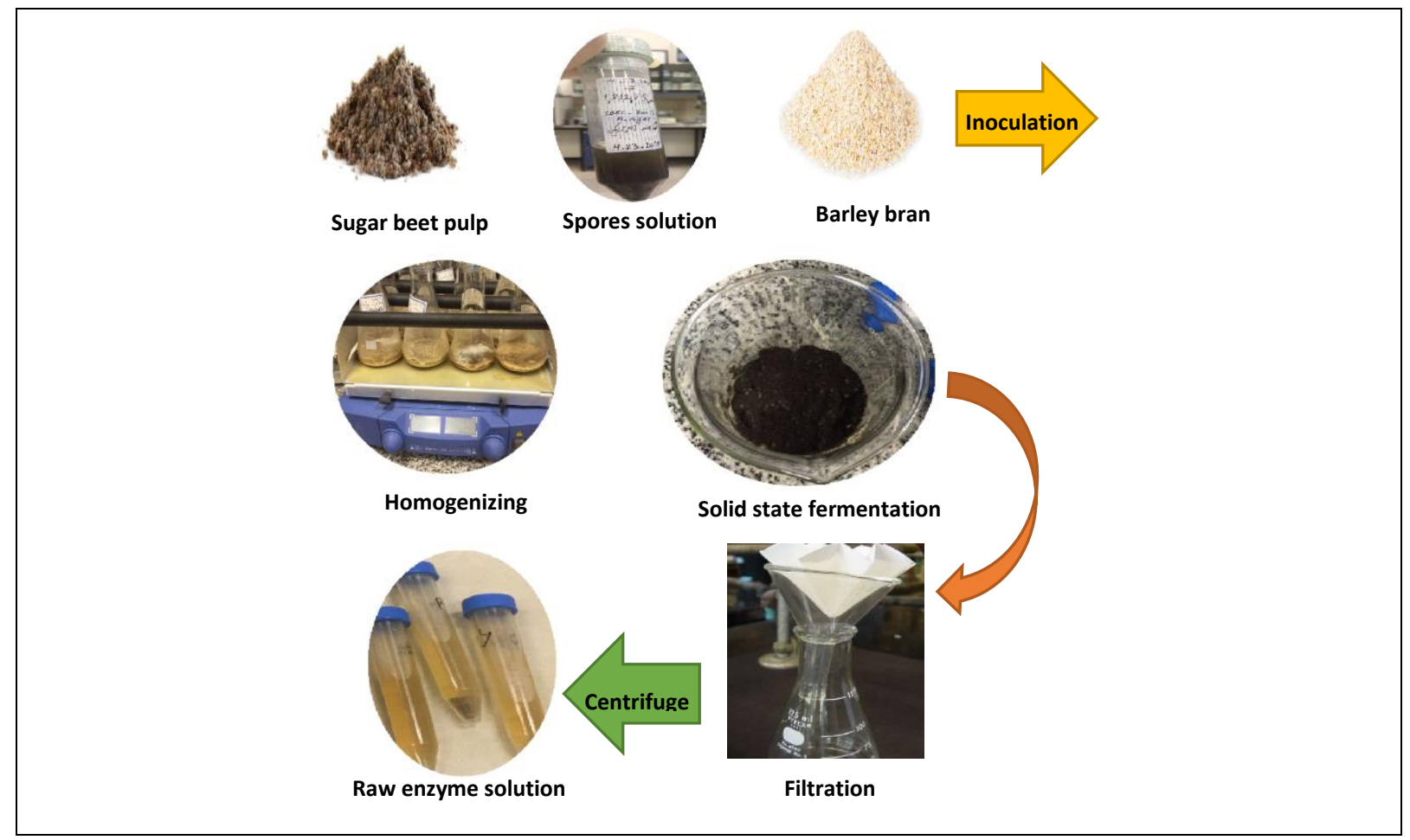




\section{Introduction}

Pectinase, an enzyme in commercial terms including polygalacturonase (PG), pectate lyase (PL), and pectin esterase (PE), is a well known enzyme that catalyses the degradation of pectic polymers in plant cell walls. This enzyme splits polygalacturonic acid into monogalacturonic acid by opening glycosidic linkages [1-3]. The commercial uses of this enzyme were first introduced in the 1930s for the preparation of juices. Today, pectinase is one of the most widely used enzymes in the industrial and biotechnology sections [4].

Now a day's pectinase are used extensively in food industry including oil extraction, manufacture of pectin-free starch, textile, refinement of vegetable fibers, plant fiber processing, extraction and clarification of fruit juices and wines, virus removal, coffee and tea fermentation, paper production, treatment of industrial wastewater containing pertinacious material, and this enzyme account for 25\% of the global food enzyme sales [5-12].

Many fungi, yeast [13] and bacteria [14] can produce this enzyme. Although the enzyme also has a plant source, it is technically and economically important to produce this enzyme in a microbial method [3]. Approximately, all commercial preparations of pectinases are produced from fungal sources [15]. Aspergillus niger is the most common fungal species used for the production of industrial pectinolytic enzymes [16-18]. This enzyme is isolated from soil and decaying fruits [19].

Submerged fermentation (SMF) and solid state fermentation (SSF) have been successfully used in the production of pectinase by fungi [20-23] and bacteria [2428]. Solid state fermentation refers to a process in which the growth of microorganisms and the production of the product occur on the surface of the solid substrate and in the vicinity of moisture [29]. Economically and operationally, the production of pectinase enzyme by solid state fermentation has many advantages over widely used submerged methods such as simplicity, more concentrated obtained metabolites, high productivity, less risks of bacterial contamination due to small water use, simpler reactor designs with minimum controls [8,9 and 30].

Several agro-industrial waste and byproducts like as rice bran, sugar cane bagasse, orange bagasse, sugar beet pulp, wheat bran and other food processing waste are suitable substrates for pectinase production by solid-state fermentation [1929]. But as far as we know, no reports have been presented about barley bran as SSF substrate or mixture of barley bran and sugar beet pulp with fungi so far. In this work, mixture of barley bran and sugar beet pulp was successfully used as substrate for polygalacturonase, the most abundant and extensively studied of the pectinolytic enzymes, production by SSF and effective factors on SSF efficiency such as temperature, inoculation amount, fermentation time, moisture percent, and weight percent of substrate mixture were investigated and optimized.

\section{Experimental}

\section{Materials}

Aspergillus niger ATCC 16404 was received from Iran National Center for Genetic and Biological Reserves in solution of $0.1 \%$ tween 20 surfactant. Barley bran was from koorosh chain store (Tehran, Iran). For sugar beet pulp preparation, fresh sugar beet was purchased from the Tehran fruits and vegetables market (Iran). Thereafter, it was well washed and peeled and sugar beet juice was extracted by a grinder, and the resulting pulp was dried in an oven at $80^{\circ} \mathrm{C}$ for 3 days. 
3,5-Dinitrosalicylic acid (DNS), galacturonic acid, and pectin citrus were from Merck. Acetate sodium and Tris were from Sigma Aldrich and other chemicals were from analytical grade.

\section{Solid state fermentation}

Solid-state fermentation (SSF) was carried out using a $250 \mathrm{~mL}$ Erlenmeyer flask containing $5 \mathrm{~g}$ of sterilized barley bran and

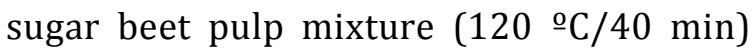
inoculated with 50 millions spores (suspended in sterile Tween 20 solution), 10 $\mathrm{mL}$ of nutrient salts solution, containing $0.1 \% \mathrm{NH}_{4} \mathrm{H}_{2} \mathrm{PO}_{4}, 0.1 \% \mathrm{NH}_{4} \mathrm{NO}_{3}$, and $0.1 \%$ $\mathrm{MgSO}_{4} \cdot 7 \mathrm{H}_{2} \mathrm{O}$ and $10 \mathrm{~mL}$ acetate buffer $\mathrm{pH} 5$. The Erlenmeyer flask lid was tightly covered by paraffin film. Resulted mixture was incubated $30 \stackrel{\circ}{\circ}$ for 7 days. After this period, obtained mixture mixed with $4 \mathrm{~mL}$ acetate buffer, stirred for $30 \mathrm{~min}$, and filtered and centrifuged. The obtained supernatant was used as crude enzyme solution [22].

DNS reagent for enzyme activity assay was prepared as follows:

$0.16 \mathrm{~g}$ of $\mathrm{NaOH}$ was dissolved in $50 \mathrm{~mL}$ of distilled water, then $1 \mathrm{~g}$ of dinitrosalicylic and 25 grams of Potassium sodium tartar tetra hydrate were well dissolved in solution. Then the final volume of the solution is reached to $100 \mathrm{~mL}$ and stored it in a dark place for subsequent measurements [31].

To measure the activity of the produced polygalacturonase enzyme, $0.5 \mathrm{~mL}$ of enzyme solution (after filtering and centrifuging the SSF mixture and diluting) was added to $0.8 \mathrm{~mL}$ of citric acid pectin (1\% $(\mathrm{w} / \mathrm{w})$ and incubated for 10 minutes at 40 ${ }^{\circ} \mathrm{C}$, then $1.5 \mathrm{~mL}$ of DNS was added and left 5 min to boiling water. The absorbance of the solution at $540 \mathrm{~nm}$ was read by UV-vis spectrophotometer [29].

The observed absorbance at $540 \mathrm{~nm}$ was correlated to micro grams of galacturonic acid by standard calibration curve of galacturonic acid (micro gram of galacturonic acid $v s$. absorbance at $540 \mathrm{~nm}$ ), and then enzyme activity calculated as $\mathrm{U} / \mathrm{mL}$ by equation (1) [32]:

$\frac{\text { galacturonic acid }(\mu \mathrm{g})}{212.12} \times\left(\frac{1}{10}\right) \times\left(\frac{1}{0.5}\right)(1-1)=$ $(\mathrm{U} / \mathrm{ml})$ enzyme activity

Where, 212.12 is molecular weight of galacturonic acid, 10 refers to enzyme solution incubation time (in minutes) with pectin citrus solution and 0.5 is volume of enzyme solution (in $\mathrm{mL}$ ). Finally, by considering total weight of dry substrate (barley bran and sugar beet pulp mixture), all measured activities were reported as $\mathrm{U} / \mathrm{g}$ (enzyme units per gram of dry substrate).

\section{Results and discussion}

Applying optimized amount for inoculation, barley bran and sugar beet pulp weight ratio and physico-chemical factors for fermentation like temperature, incubation time, and moisture content strongly affect the fungi growth and enzyme production efficiency [30], so the effect of mentioned factors on produced enzyme activity was investigated and optimized amounts were selected.

\section{Effect of barley bran/sugar beet pulp ratio}

Produced enzyme activity was assayed in different weigh percent of sugar beet pulp in mixture with barley bran. Here there are two substrates (sugar beet pulp and sugar cane bagasse) to grow and proliferation of fungi in the environment. Growth of the fungus follows a variety of patterns when two substrates in bulk. One pattern is that the microorganism consumes both substrates at the same time, which in this case fungi usually has a better growth and another pattern is alternative consumption of substrates, in which microorganism firstly used the richest substrate, and 
between the replacement of a substrate, a lag phase (in terms of fungal growth and production of enzymes) may be observed [33]. In addition to the fact that the type of substrate (the type of nutrient compounds present in the substrate) can influence the growth of the fungus, the particle shape of the substrate is also important, since the barley bran has a much smaller particle size than that of the sugar beet pulp. Despite its high porosity, it is easily integrated in a moist environment, which can prevent aeration and oxygenation of fungi. However, barley bran has high levels of carbon content and nutrients and has the high ability to keep microorganisms at its surface. Result of this section was shown at Figure 1. As can be seen highest enzyme activity is on 50:50 weight ratio of barley bran to sugar beet pulp ratio. It seems that disadvantageous properties of barley bran (integrating particles in moisture and lowering aeration to fungi) overcome to advantageous ones prior to ratio of 50:50, because the enzyme activity was increased with decreasing the barley bran percent in mixture. Thereafter it was overcome by the desirable properties like high carbonic content and high porosity. Finally with increasing sugar beet pulp percent above the $80 \%$, enzyme activity was increased again. According to mentioned results, weight ratio of 50:50 was regarded as optimized one.
Figure 1. Effect of weight percent of sugar beet pulp in mixture with barley bran on enzyme activity

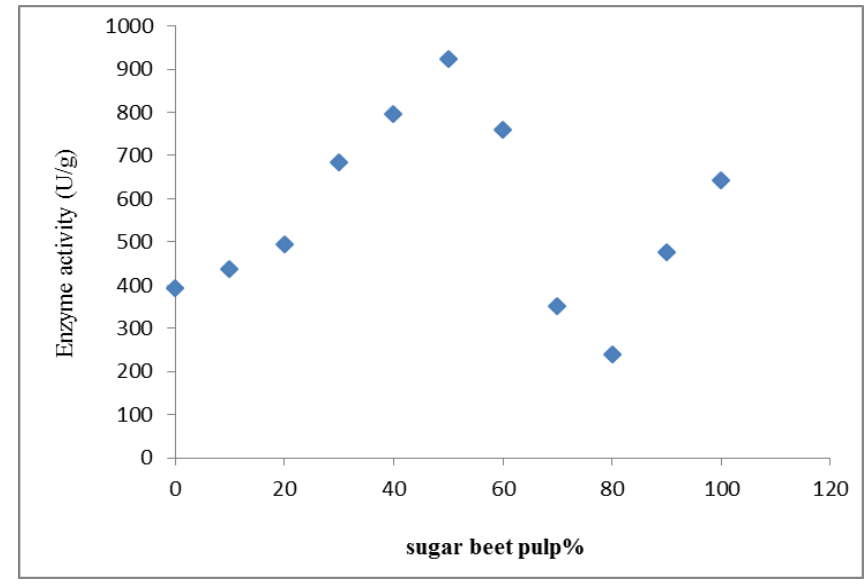

amount for subsequent experiments. It is worth noting by using 50 million spores according to the results, nearly $98 \%$ of the enzyme activity is observed compared to when 75 million spores are used, but due to the close proximity of activities and high cost and the difficulty of providing spores, the 50 million spores can be considered as optimal inoculation amount. A similar result has been observed for the number of optimal spores in producing pectinase from sunflower head by Aspergillus niger in solid state fermentation [34]. 
Figure 2. spores count effect on produced enzyme activity

Figure 3. Incubation time effect on produced enzyme activity

\section{Incubation time effect}

It is very important to find the optimal time for fermentation to produce the enzyme, because this is the time when fermentation is stopped and enzyme must be extracted. In other words, the enzyme activity is in its maximum. In later times, the use of nutrients and the reduction of their levels, the decrease in oxygen concentration and the high density of fungal cells occur. Low incubation time leads to an enzyme with low activity and excessive times required to increase the risk of environmental contamination. Also, high temperatures due to the release of heat from the metabolites can cause abnormalities of the enzyme (denaturation), or the enzyme deactivated by secondary metabolites, proteases or shift of $\mathrm{pH}$ in the environment [35-37]. The results are shown in Figure 3. As seen, the activity of the enzyme increases with a steep slope up to the first 3 days and then continues to increase slower until the seventh day and then significantly decreases so that on the twenty-fifth day
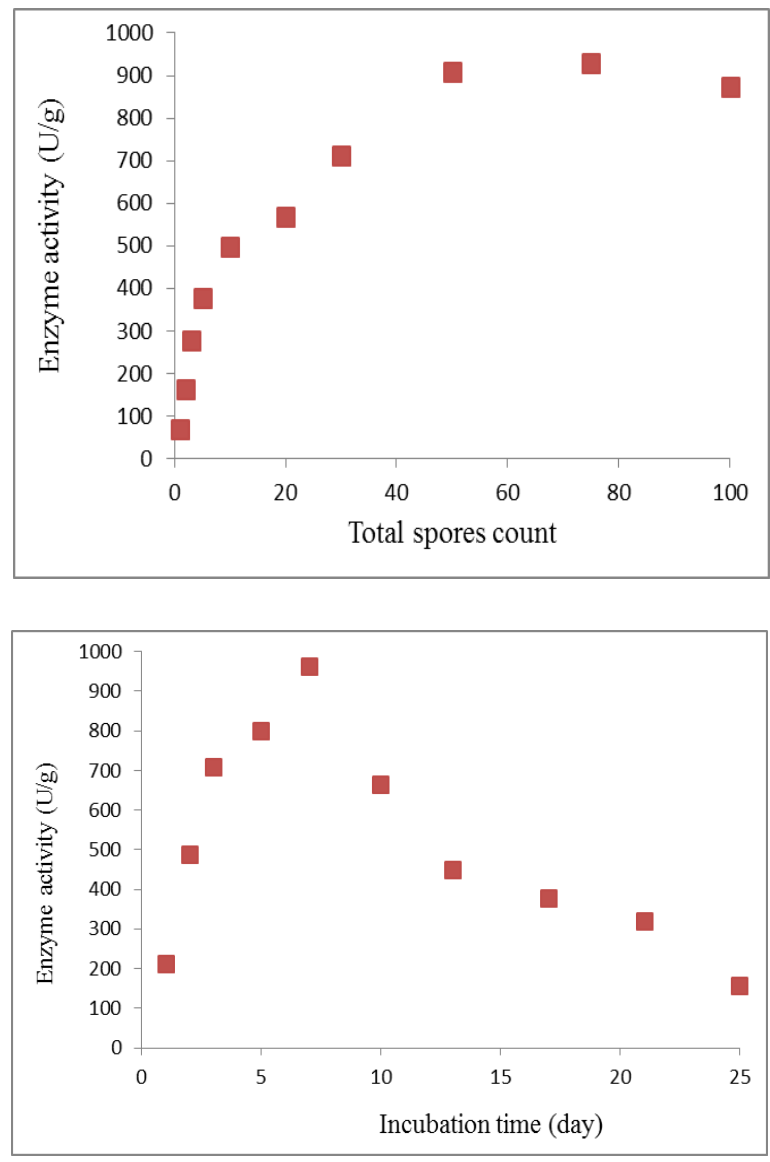

approximately $16 \%$ of its maximum value (on the seventh day) is observed. Therefore, the 7 day duration was regarded as the optimal time for maximum enzyme activity. Martin et al., observed similar results (optimal time of 8 days) for the polygalacturonase enzyme produced with monilia spp. SB9 with orange bagasse, sugar cane bagasse and wheat bran [38].

\section{Fermentation temperature effect on enzyme} activity

Temperature is known as the most important factor in the production of enzymes in many fermentation processes, both in solid state fermentation and in submerged fermentation method. The temperature provides energy for growth and metabolic activity for microorganisms [38]. In the early stages of growth and when the lag phase is over, the increase in temperature will not be favorable for the growth and production of the enzyme, because more energy absorption 
reduces the time of microorganism adaptation to growth conditions. Therefore, bypassing the lag stage, there is no need for high temperature, and only a rise in temperature reduces the number of living cells according to Equation 2:

$$
\mathrm{X}_{\mathrm{t}}=\mathrm{X}_{0} \exp (-\mathrm{kt})
$$

Where $X_{t}$ is the number of live cells at temperature $t$ and $X_{0}$, the number of primary cells and the $\mathrm{k}$ is death constant that increases with temperature rise [33]. In this section, the effect of incubation temperature was investigated for 7 days at 20 , 30,40 and $50{ }^{\circ} \mathrm{C}$ on the activity of the produced enzyme and the results were presented in Figure 4. It can be seen that an increase in incubation temperature from $20{ }^{\circ} \mathrm{C}$ to $30{ }^{\circ} \mathrm{C}$ resulted in an increase of about $24 \%$ in enzyme activity and an increase in incubation temperature up to $40{ }^{\circ} \mathrm{C}$ resulted in a sudden

Figure 4. effect of fermentation temperature on enzyme activity

Figure 5. Effect of moisture content on enzyme activity drop in enzyme activity and enzyme activity decreased by $51 \%$. This decrease in activity was continued to $50{ }^{\circ} \mathrm{C}$, so that at $50^{\circ} \mathrm{C}$, enzyme has $65 \%$ of its maximum activity at $30^{\circ} \mathrm{C}$. Hours et al., (1987) obtained a very close result, which yielded 980 units/g dry matter at an optimum temperature of $30{ }^{\circ} \mathrm{C}$ using Aspergillus foetidus using apple peel [39].

\section{Effect of moisture content on enzyme activity}

The effect of moisture content (relative to total mixture weight) on the activity of the enzyme was investigated and the results are presented in Figure 5. As shown in the figure, the enzyme activity was greatly affected by moisture content in moisture range of $68 \%$ to $80 \%$. By increasing moisture, the enzyme activity has increased significantly, which shows the urgent need of microorganisms to water for growth and metabolism.
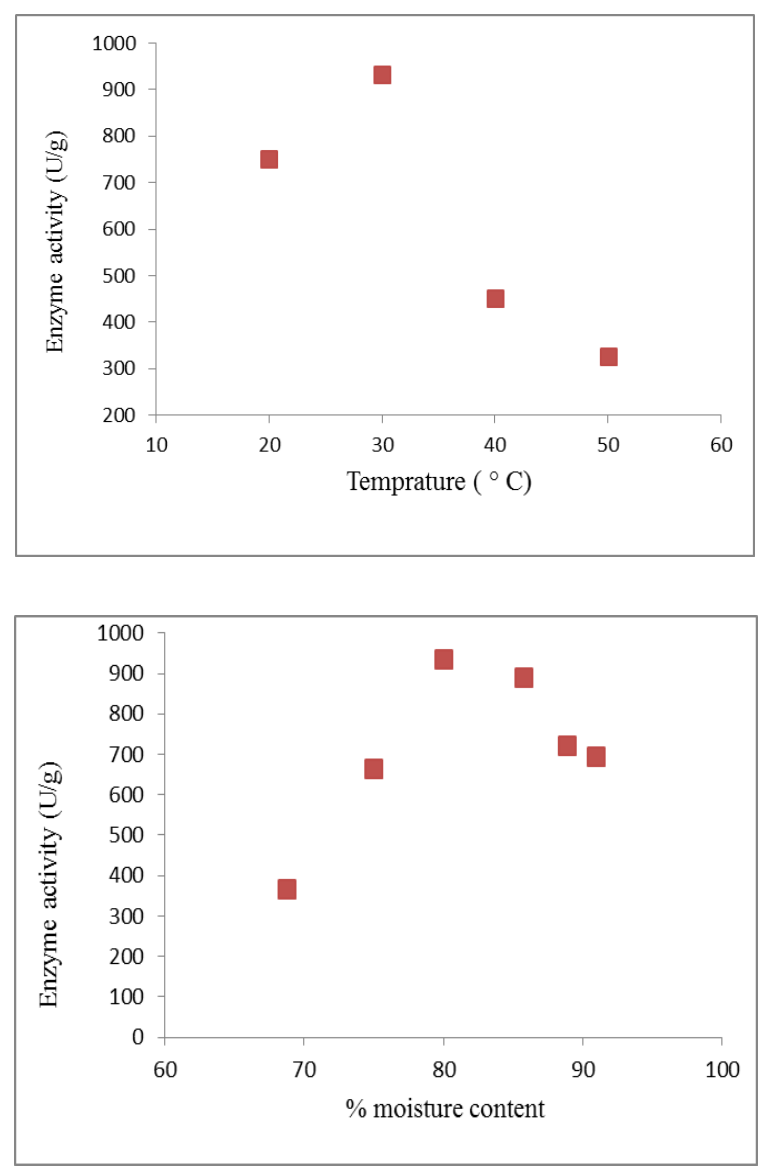
On the other hand, by increasing the moisture content to above $80 \mathrm{wt} \%$, the decrease in activity of the enzyme is observed, when high moisture content can reduce porosity, decrease the oxygen penetration and gas volume, and also increase the probability of bacterial contamination and formation of air mycelium. It can be concluded that all of these factors can reduce enzyme activity in high levels of moisture [40]. In many studies, the initial moisture content was reported by 40 to $75 \%$, which decreased during fermentation due to the evaporation and metabolism of fungi $[21,35$ \& 41].

\section{Conclusion}

Barley bran/sugar beet pulp mixtures were successfully applied as carbon source for Polygalacturonase production by solid state fermentation with Aspergillus niger strain. Affecting factors on produced enzyme activity including carbon sources relative composition, fermentation time, fermentation temperature, inoculation amount, and moisture content were investigated and optimized amounts were selected. Very likely to observed regime of enzyme activity changes under the influence of mentioned factors were reported by previous works. It's worth to say that the highest obtained enzyme activity (under optimized factors) in this work was above the $900 \mathrm{U} / \mathrm{g}$ which is significantly more than many reported researches. Finally this research nominated barley bran/sugar beet pulp mixture as a highly efficient, low cost and easy to supply carbon source to pectinase production.

\section{Acknowledgment}

This work was made possible by the support of the Science and Research Branch, Tehran Islamic Azad University.

\section{Disclosure statement}

No potential conflict of interest was reported by the authors.

\section{References}

[1] M.V. Semenova, S.G. Grishutin, A.V. Gusakov, O.N. Okunev, A.P. Sinitsyn, Biochemistry (Moscow), 2003, 68, 559-569.

[2] W.M. Fogarthy, O.P. Ward, Prog. Ind. Microbiol., 1974, 13, 61-119.

[3] A. Khan, S. Sahay, N. Rai, Res. Biotechnol., 2012, 3, 19-25.

[4] M. Akhter Asifsiddiqui, V. Pande, M. Arif, Hin. Pub. Corpo. Enzyme Res., 2012, 8, 234-241.

[5] G. Hoondal, R. Tiwari, R. Tewari, N. Dahiya, Q. Beg, App. Microbiol. Biotechnol., 2002, 59, 409418.

[6] K.R. Sreekantiah, Ind. Food Packer, 1975, 29, 22-36.

[7] J.R. Whitaker, Pectic enzymes. In: Principles of Enzymology for the Food Sciences (Food Science and Technology-Series of Monographs, Textbooks and Reference Books), 2nd Ed, New York: Marcel-Dekker, 1994, p. 426.

[8] B.K. Lonsane, M.V. Ramesh, Adv. Appl. Microbiol., 1992, 15, 1-48.

[9] M.R. Trejo-Hernendez, E. Oriol, A. LopezCanales, S. Roussos, G. Viniegra, M. Raimbault, Micol. Neotrop. Apl., 1991, 4, 49-62.

[10] L. Salazar, U. Jayasinghe. Fundamentals of purification of plant viruses. In: Techniques in plant, virology, CIP., Training Manual, J.O., Virus Purification. Peru: International Potato Centre: 1999, pp. 1-10.

[11] L. Viikari, M. Tenakanen, A. Suurnakki. Biotechnology in the pulp and paper industry. In: Rehm HJ. Biotechnology, VCH-Wiley; 2001, pp. 523-546.

[12] I.D. Reid, M. Richard, Enzyme and Microbial Technology, 2004, 34, 499-504.

[13] T. Sakai, M. Okushima, M. Sawada, Agricultural and Biological Chemistry, 1982, 46, 2223-2231.

[14] Y. Itoh, J. Sugiura, K. Izaki, H. Takahashi, Agricultural and Biological Chemistry, 1982, 46, 199-205. 
[15] S.A. Singh, M. Ramakrishna, A.G.A. Rao, Process Biochemistry, 1999, 35, 411-417.

[16] P.Kotzekidov, J. Ind. Microbiol. 1991, 7, 5356.

[17] F.M. Barnby, F.F. Morpeth, D.L. Pyle, Enzyme and Microbial Technology, 1990, 12, 891-897.

[18] G.S.N. Naidu, T. Panda, Bioprocess Engineering, 1998, 19, 355-361.

[19] N. Jacob, P. Prema, Food Technology and Biotechnology, 2006, 44, 263-267.

[20] D. Dinu, M.T. Nechifor, G. Stoian, M. Costache, A. Dinischiotu, Journal of Biotechnology, 2007, 131, 128-137.

[21] L.R. Castilho, R.A. Medronho, T.L.M. Alves, Bioresource Technology, 2000, 71, 45-50.

[22] D. Silva, E.S. Martins, R. Silva, E. Gomes, Brazilian Journal of Microbiology, 2002, 33, 318-324.

[23] D.B. Pedrolli, E. Gomes, R. Monti, E.C. Carmona, Applied Biochemistry and Biotechnology, 2008, 144, 191-200.

[24] N. Jacob, A.C. Poorna, P. Prema, Bioresource Technology, 2008, 99, 6697-6701.

[25] B.G. Klug-Santner, W. Schnitzhofer, M. Vrsanská, J. Weber, P.B. Agrawal, V.A. Nierstrasz, G.M. Guebitz, Journal of Biotechnology, 2006, 121, 390-401.

[26] D.R. Kashyap, S. Chandra, A. Kaul, R. Tewari, World Journal of Microbiology and Biotechnology, 2000, 16, 277-282.

[27] M. Soriano, P. Diaz, F.I.J. Pastor, Current Microbiology, 2005, 50, 114-118.

[28] S.N. Gummadi, D.S. Kumar, Biochemical Engineering Journal, 2006, 30, 130-137.

How to cite this manuscript: Aboalhasan Alavi, Farahnoosh Tahghighi Nia, Farshid Pajoum shariati, Polygalacturonase Production by Aspergillus Niger Solid State Fermentation on Barley

Bran and Sugar Beet Pulp Mixture, Adv. J. Chem. A, 2020, 3(3), 350-357.
[29] N. Martin, S.R. Souza, R. Silva, E. Gomes, Brazilian Archives of Biology and Technology, 2004, 47, 813-819.

[30] S. Annapurna Singh, M. Ramakrishna, A.G. Appu Rao, Process Biochemistry, 1999, 35, 411417.

[31] R.L. Zbîrcea, G. Menghiu, A. Matica, V .Ostafe, New Front. Chem., 2016, 25, 145-153.

[32] C. Tari, N. Gogus, F. Tokatli, Enzyme and Microbial Technology, 2007, 40, 1108-1116.

[33] E. Taşkın, R. Eltem, Food Biotechnology, 2008, 22, 203-217.

[34] S. Patil, A. Dayanand, Bioresource Technology, 2006, 97, 2340-2344.

[35] A. Blandino, T. Iqbalsyah, S. Pandiella, D. Cantero, C. Webb, Applied Microbiology and Biotechnology, 2002, 58, 164-169.

[36] S. Ramachandran, A.K. Patel, K.M. Nampoothiri, F. Francis, V. Nagy, G. Szakacs, A. Pandey, Bioresource Technology, 2004, 93, 169174.

[37] A. Pal, F. Khanum, Bioresource Technology, 2010, 101, 7563-7569.

[38] R.P. Sarvamangala, A. Dayanand, Bioresource Technology, 2006, 97, 2340-2344.

[39] R.A. Hours, C.E. Voget, R.J. Ertola, Biol. Waste, 1988, 24, 147-157.

[40] E.S. Martins, D. Silva, R. Silva, E. Gomes, Process Biochemistry, 2002, 37, 949-954.

[41] P. Freitas, N. Martin, D. Silva, R. Silva, E. Gomes, Brazilian Journal of Microbiology, 2006, 37, 302-306. 